\title{
POST-LARYNGECTOMY THERAPY: A COMMUNICATION APPROACH
}

\author{
ERNA ALANT MA. (LOG.) (PRET.) \\ Department Speech Pathology and Audiology, University of the Witwatersrand, \\ Johannesburg
}

\begin{abstract}
SUMMARY
This article deals with the interpretation of post-laryngectomy therapy within the framework of communication.

The communication approach towards rehabilitation emphasizes the necessity of incorporating verbal communication and non-verbal communication into the diagnostic and therapy procedures because of the close link between the two modes of communication.

Diagnosis and therapy are discussed in terms of communication skills, social and personal sensitivity and tension. Throughout the article, the stress is on the therapist's creative role in the laryngectomy patient's construction of reality.
\end{abstract}

\section{OPSOMMING}

Die artikel handel oor die interpretasie van post-laringektomie terapie binne die raamwerk van kommunikasie. Die kommunikasie benadering tot rehabilitasie beklemtoon die noodsaaklikheid van die interpretasie van verbale sowel as nie-verbale kommunikasie in terapie. Die noue verband tussen verbale en nic-verbale kommunikasie in die algemene kommunikasiepatroon van die individu noodsaak dit.

Diagnose en terapie word bespreek in terme van kommunikasie vaardighede, sosiale en persoonlike sensitiwiteit sowel as spanning. Dwarsdeur die artikel is die klem op die terapeut se kreatiewe rol in die laringektomie pasiënt se konstruksie van realiteit.

Communication is seen as the process of creating meaning intersubjectively; ${ }^{1,4}$ it is the way in which the individual interacts with the people and "things" around him in order to achieve a situation that makes sense to him.

Furthermore, meaning is achieved by using verbal and non-verbal means. Verbal communication is usually taken to be the most important mode of communication, and it has therefore been the focus of rehabilitation procedures over a number of decades. ${ }^{14}$ Although one could not deny the importance of verbal interaction, it is important to interpret and diagnose a communication problem within the framework of the overall communication pattern of the individual. ${ }^{16}$ When dealing with the problem of the laryngectomy patient and the sudden trauma of "not being able to: speak", the therapist tends to start remediating on the immediate problem which is vocal sound production. ${ }^{6,10}$

The communication process is disturbed because of a sudden inability of the individual to communicate verbally as before, and because of the close link between verbal and non-verbal communication the loss of speech also impairs the patient's non-verbal means of expression. ${ }^{5}$

The South African Journal of Communication Disorders, Vol. 27, 1980 
Interaction between the individual and his fellow-men changes, not only because of the different speech pattern and voice the patient has acquired in the process, but also because of the changed conceptions of 'self' and 'other' amongst all participants in the social situation.

Boone $^{6}$ stresses that rehabilitation starts when the surgeon tells the patient that he has cancer. This approach to laryngectomy therapy emphasizes the need for psychological counselling of the patient as well as his family. Counselling does not only include talking about the operation, but also preparing the patient and his family for the varied consequences of the operation.

The emphasis in laryngectomy therapy over the last decades was on counselling the patient and his family and applying techniques to re-initiate verbal communication (by means of esophageal speech, artificial larynx etc.). As Dietrich and Strom ${ }^{9}$ point out: We have $a$ greater responsibility to the laryngectomee than just teaching him how to produce sounds or even simple words.

The main concern is for the patient to be intelligible and that the quality of his speech should be socially acceptable in order for him to be able to go back to his previous work situation. Although the above approach sounds logical, interaction is defined in terms of verbal communication (VC) only. The implication is that the patient has "lost speech" and should be able to interact without strain as soon as he can "speak again". The therapist will focus on counselling the patient on the physical difficulties he might have with his stoma etc. However, the influence that the problem will have on his general interaction with people on account of the different way in which they will perceive him, as well as his changed perception of himself, is neglected. Also, the communication pattern of the individual (although he might be a good esophageal speaker) will be changed due to the intricate relationship between verbal and non-verbal communication. To concentrate only on verbal rehabilitation is thus not aiding the communication process to the fullest extent. The verbal communication of the patient will never be the same as before the operation, for example, stress patterns become more difficult, frequently there is a drastic reduction in the speech rate, pauses increase, pitch becomes lower.

In order for the patient to communicate effectively, non-verbal communication (NVC) will have to be adjusted in order to support verbal communication. Although one could argue that this might happen spontaneously, there is no guarantee that this will happen. Further the therapist could facilitate this process. The communication approach towards therapy stems from the realization that a patient's social participation would be the basic focus of therapy and not merely the improvement of his/her verbal ability. This means that the therapist herself has to achieve understanding and awareness of the underlying sensitivities of the patient's situation in order to be able to rehabilitate communication. This, amongst other things, would imply that the therapist does not 
approach the therapeutic situation in a clinical (technical) manner but rather attempts to situate the therapy within the life-world of the patient. Let us now be more explicit about the criteria for evaluating the communication of a laryngectomy patient. The communication of a laryngectomy patient could be diagnosed according to communication skills, social and personal sensitivity and tension.

\section{COMMUNICATION SKILLS}

This would include analysing his verbal and nonverbal communication skills as well as the way in which the patient combines both in daily interaction.

Verbal Communication Analysis

Speech: The articulation of the patient should be assessed as well as the air-intake method. Berlin ${ }^{3}$ describes further criteria for evaluating speech production in laryngectomy patients by measuring the latency period between the air intake and the production, ability to phonate reliably on command, maintenance of an optimal duration of phonation, speech rate etc.

Language: This is important in that clear verbal expression can facilitate overall communication. Bad speech habits, for example frequent repetitions, ungrammatical utterances could indeed impede communication. ${ }^{1}$

Paralanguage: This is particularly important because esophageal speakers frequently have difficulty in maintaining sufficient loudness throughout conversations. Pitch changes and intonation are also difficult due to frequent pauses and slowed speech. ${ }^{15}$

Nonverbal Communication Analysis:

In this section the therapist would analyse what kind of NVC the patient uses, for example gestures, facial expressions, leg and foot movements and body shifts. She would also attempt to analyse the function of these NVC's in supporting verbal communication, ${ }^{2}$ completing the verbal messages, substituting for verbal communication or facilitating the actual production of esophageal speech. ${ }^{12}$ This last aspect becomes increasingly important when evaluating excessive tension and effort in the production of esophageal speech. Excessive tension might manifest itself in, for example facial distortion and body shifts.

SOCIAL AND PERSONAL SENSITIVITY

Apart from verbal and nonverbal skills, effective communication also demands awareness or sensitivity to the needs of others as well as the needs of oneself. ${ }^{1}$ In the case of the laryngectomy patient this aspect is no less important than the actual improvement of communication skills. It is vital that the patient is aware of how others perceive the problem and how they define his communication problem. Accordingly therapy should facilitate his reactions and responses in interpersonal 
contacts. ${ }^{2}$ At the same time, the patient should be aware of what he wants to achieve and how this could be done realistically.

Social Sensitivity would-include-aspects like.the following:

How aware is the patient of the social demands on him? Does he frequently interact with people? Is he ashamed of his stoma? Does he tend to cover the stoma with cravats that are socially attractive but uncomfortable? To which extent is he changing his behaviour in order to be accepted by other groups? For example, does he identify and become actively involved in the local laryngectomy society or any other organization of this type?

Personal sensitivity could include the following: How aware is the patient of himself, his problem and its implications for his life style? Can he still actively participate in the activities that he enjoys? Can he initiate conversations? How expressive is he of how he feels and experiences his problem? How motivated is he to overcome the problem?

It is difficult to be dogmatic about the distinction between social and personal sensitivity as they are interrelated. The therapist should, however, aim at devising criteria which could distinguish between a predominantly social or predominantly personal sensitivity.

\section{TENSION}

Various authorities in the field of laryngectomy emphasize the importance of tension management in effective communication (good esophageal speech production). ${ }^{6,10,15}$ Tension is important due to the influence on the performance of the cricopharyngeal muscle when producing esophageal speech. Excessive tension could result in excessive stomal noise, audible intake of air, indigestion problems due to swallowing of air etc. It is important that the therapist identifies the way in which tension manifests itself in the patient. Tension does not only hinder the effective production of esophageal speech, it also impedes overall communication on different levels, for example the individual's limited sensitivity towards others and himself.

Table I summarizes the diagnostic procedures:

\section{PRINCIPLES OF REHABILITATION}

From the diagnostic procedures three basic areas of rehabilitation emerge:

\section{Improving Communication Skills}

The improvement of verbal and nonverbal skills entails the identification of ineffective verbal and nonverbal communication, behaviour change and the development of more effective communication strategies. In the laryngectomee's case this would include verbal rehabilitation including other verbal communicative aspects such as intonation, language etc. Most of these aspects of therapy could be done by auditory training and self-monitoring. 


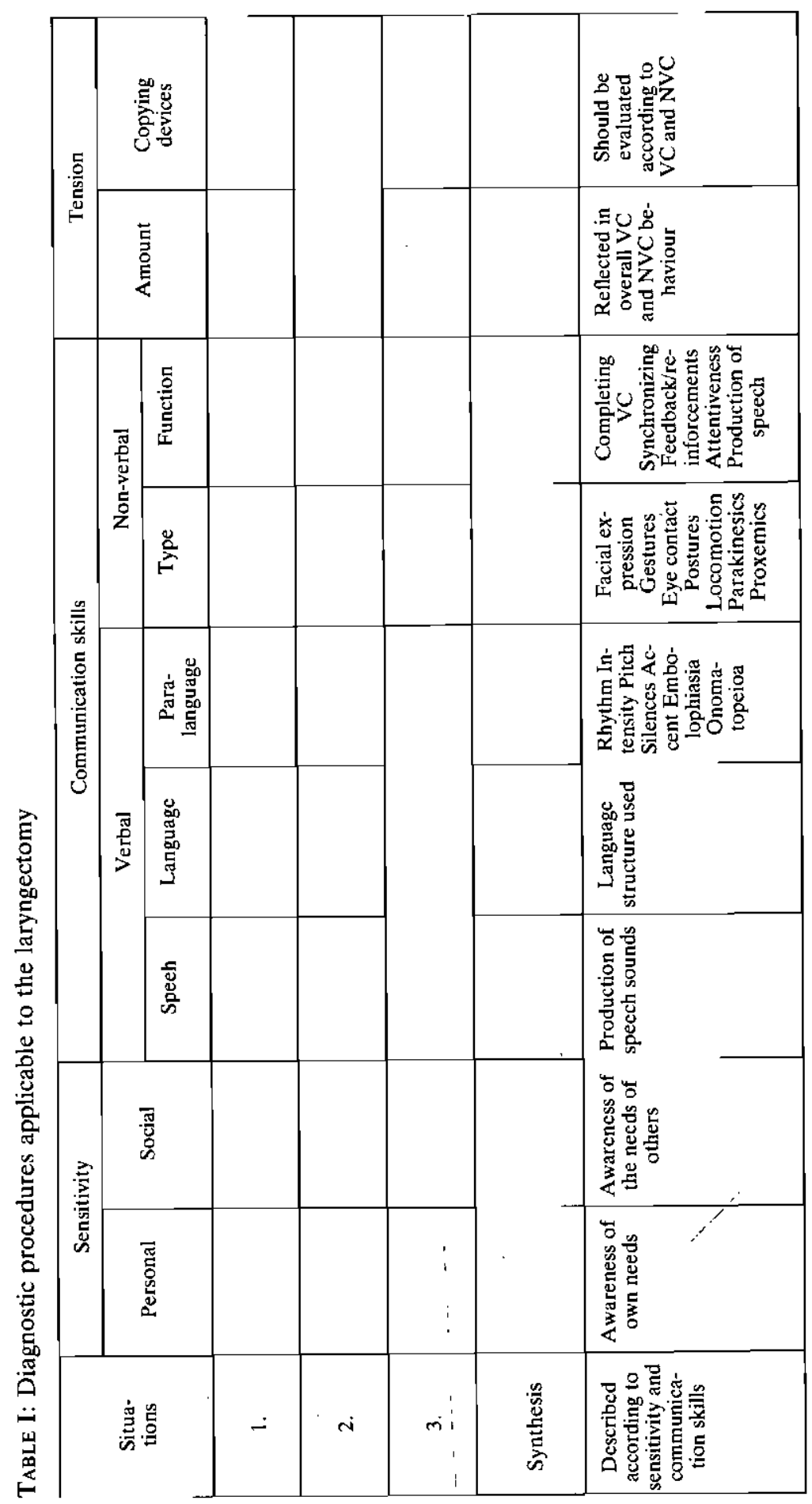

The South African Journal of Communication Disorders, Vol. 27, 1980 
The reconstruction of non-verbal systems has until now received very little attention in therapy; this could partly be due to the fact that it is difficult to standardise non-verbal communication patterns as these do not seem to be as readily objectifiable as verbal speech patterns. It is important that the therapist therefore not only studies the personal non-verbal style of the patient, but also acquires sensitivity to the demands of the patient's new situation. The therapist thus helps the patient to enhance his/her non-verbal skills in order to compensate for the loss of verbal facility and so to 'complete' the verbal message. This can be done by using video tapes, slides or any other visual presentation that could facilitate the explanation and observation of non-verbal communication.

By explaining how non-verbal means can contribute to more effective communication, the therapist can encourage the patient to experiment in order to change and improve his own pattern of interaction.

\section{Increasing Social and Personal Sensitivity}

In this part of therapy, the therapist should aim at making the patient more aware of himself and others. This could be done in conjunction with the identification and modification of verbal and non-verbal skills. Therapy would focus on interpersonal perception and how behaviour could be interpreted meaningfully in order to enhance interaction and understanding.

Social perception would include the following: How do others perceive my problem, and how can I according to that facilitate-interaction with them?

Personal Perception would include: What does the patient find particularly difficult in situations and how can interaction in the situation be facilitated, thus how can I handle situations that are difficult for me?

\section{Relaxation}

Relaxation is included in many therapy programmes with laryngectomy patients. Checklists could be used for identifying and improving relaxation. In accordance with the normal process of rehabilitation the first step will be the identification of tense areas, then on the basis of this, the formulation of a relaxation programme. The discussion on general versus specific relaxation is important here and should not be neglected. ${ }^{11}$ Most patients have difficulty with specific relaxation without the background of general relaxation. On the whole long and cumbersome general relaxation programmes can be very discouraging and demotivating on account of the apparent concentration on techniques not directly related to communication rehabilitation. It is important to be able to incorporate relaxation in a way meaningful to the patient. The procedures suggested by Jacobson ${ }^{11}$ do not necessarily apply to all patients. The therapist should have the insight into relaxation therapy to compile a realistic relaxation programme for the 
patient that will also facilitate relaxation in everyday life. Techniques like breathing, counting and associations, together with physical relaxation could indeed be included in a relaxation programme that will not demand more than twenty minutes of the patient's time. As the patient becomes more familiar with relaxation, the aim would be to shorten this programme even more in order to facilitate its use in everyday life. Relaxation therapy on its own is of little value unless the therapist is able to aid the patient in incorporating relaxation into his daily life in a way that is meaningful to him.

What the writer has attempted to do should be seen as a tentative attempt to rethink the therapist's creative role in the laryngectomy patient's construction of reality. Whether we like it or not, we, the therapists, are involved in much more than the technical reconstruction of vocal sounds: we are actually deeply involved in the reconstruction of our patients' everyday lives. And that this fact should be our focal point, constitutes the core of the present argument.

\section{REFERENCES}

1. Alant, E. (1979): Speech and Language Pathology and Communication. MA thesis, Speech Therapy, Speech Science and Audiology Department, University of Pretoria.

2. Argyle, M. (1969): Social Interaction. Methuen-London.

3. Berlin, C. I. (1965): Clinical Measurement of Esophageal Speech. J. Speech Hear. Dis. Vol. 30, No. 2. pp. 174-183.

4. Berlo, D. K. (1960): The Process of Communication Holt, Rinehart \& Winston: New York.

5. Boase, P. H. (1964) \& Eisenson, J.: Basic Speech MacMillan N.Y.

6. Boone, D. R. (1977): Voice and Voice Therapy Prentice-Hall: New Jersey.

7. Cook, M. (1971): Interpersonal perception. Penguin: London.

8. Damsté, P. H. \& de Zaayer, C. \& Kuiper, F. D. \& Scholtens, B. (1978): Het werken met gevorderde gelarymgectomeerden met behulp van een spraakbeoordelingslijst. Logopedie en Fonratrie Vol. 50, No. 7/8 pp. 277-282.

9. Diedrich, W. M. \& Strom, K. A. (1966): Alaryngeal Speech Charles, C. Thomas: Springfield.

10. Greene, M. (1980): The Voice and its Disorders, Pitman Medical: Kent.

11. Jacobson, E. (1976): You must Relax, McGraw-Hill: New York.

12. Kendon, A. (1972): Some Relationships between body motion and speech, in Siegman, A. W. and Pope, P. (Eds.), Studies in Dyadic communication. Pergamon Press: Elmsford.

13. Nagel, R. F. (1963): Against pré-laryngectomy counselling. $J$. Speech Hear Dis., Vol. 28.

14. Perkins, W. H. (1977): Speech Pathology C. V. Mosby \& Co: St. Louis. 
15. Rigrodsky, S. (1971): Therapy for the Laryngectomized Patient. Teachers College Press: Columbia.

16. Silverman, F. H. (1980): Communication for the Speechless, Prentice-Hall: New Jersey.

17. Snidecor, J. C. (1969): Speech Rehabilitation of the Laryngectomized, Charles, C. Thomas, Springfield. 